\title{
ANTIBACTERIAL ACTIVITY TEST OF LIME JUICE EXTRACT AGAINST ESCHERICHIA COLI
}

\author{
Nerdy Nerdy, Palas Tarigan, Puji Lestari, \\ Elysa Elysa, Siti Nurmalisa \\ ${ }^{1}$ Department of Pharmaceutical Chemistry, Faculty of Pharmacy \\ ${ }^{2}$ Department of Pharmaceutical Pharmacology, Faculty of Pharmacy \\ ${ }^{2}$ Department of Pharmaceutical Biology, Faculty of Pharmacy \\ e-mail: nerdy190690@gmail.com
}

\begin{abstract}
Lime (Citrus aurantifolia Swingle) is known to have seceral phytochemical contents (flavonoids and saponins) that can be has a variety of useful pharmacological activities. One of the pharmacological activities provided by flavonoids is as antibacterial activity. The aims of this research was to determine the antibacterial activity of lime juice against Escherichia coli bacteria. This research used an experimental laboratory research method using antibacterial effectiveness trials against the growth of Escherichia coli bacteria. The research design for antibacterial effectiveness used the lime fruit extract method with 4 treatment groups, positive control and negative control. Antibacterial effectiveness was observed the inhibition zone diameter by disc diffusion method. Results of the Escherichia coli antibacterial effectiveness test obtained at a concentration of $100 \%$ had antibacterial activity with an average diameter of the inhibition zone $19.9 \mathrm{~mm}$. The lowest concentration that still provides antibacterial resistance against Escherichia coli is at a concentration of $12.5 \%$ with an average diameter of the inhibition zone of $17.9 \mathrm{~mm}$. The results obtained indicated that the antibacterial effectiveness test on lime fruit extract is very strong. At a concentration of $100 \%$ it has the best antibacterial activity, the inhibition zone diameter similar with the inhibition zone of $500 \mathrm{mg}$ tetracycline.
\end{abstract}

Keywords: Antibacterial; Lime; Escherichia coli

\section{BACKGROUND}

One of the plants that can be used as ingredients in traditional medicines is lime (Citrus aurantifolia Swingle). Lime is known to have flavonoids that can be used as antioxidants, and a higher concentration of flavonoids is found in the skin of lime compared to other parts such as seeds, fruit, juice of lime which has slightly lower flavonoids. The content of flavonoids with a higher concentration in the peel makes lime has antibacterial and antioxidant power (Lin et al., 2019).

Lime is often used to treat various diseases, such as constipation, irregular menstruation, diphtheria, acne, 
headache or vertigo, shortness of voice, cough, body odor, increase appetite, prevent hair loss and inflammation of the nose (Agoes, 2010). Figure 1 show Lime (Citrus aurantifolia Swingle) Fruit.

Figure 1. Lime (Citrus aurantifolia Swingle) Fruit

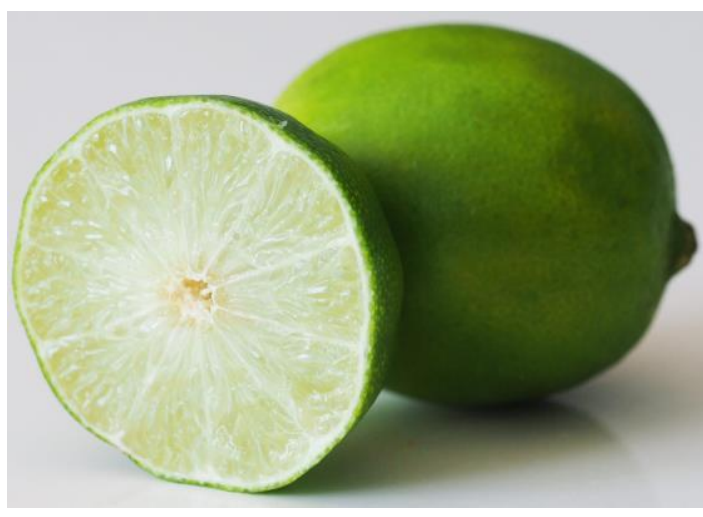

Lime (Citrus aurantifolia Swingle) is one type of citrus which contains beneficial chemical compounds (citric acid, amino acids, essential oils, resin, glycosides, calcium, phosphorus, iron, sulfur, and vitamins). In addition, lime also contains saponins and flavonoids, namely hesperidin, tangeretin, naringin, and eriocitrin (Adindaputri dkk., 2013). The purpose of this study was to determine the antibacterial activity of lime juice against Escherichia coli bacteria.

\section{METHODS}

This study used an experimental laboratory research method using antibacterial effectiveness trials against the growth of Escherichia coli bacteria. Antibacterial effectiveness research used a completely randomized design (homogeneous design) to give an effect on observed antibacterial activity. The research design for antibacterial effectiveness used the lime fruit extract method with 4 treatment groups, positive control and negative control.

\section{Tools}

The tools used for the research include petri dishes (Iwaki), conical flask (Iwaki), Reaction tube (Iwaki), beaker glass (Iwaki), measuring glass (Iwaki), autoclave (Thermo), hotplate (Thermo), analytical balance (Sartorius), refrigerator (Panasonic), binocular microscope (Zeiss), laminar air flow (Thermo), and other glassware with analytical grade.

\section{Materials}

Materials used for research include lime fruit (obtained from Deli Tua traditional market located in Deli Tua Timur, Deli Tua, Deli Serdang, Sumatera Utara, Indonesia, 20355), pure culture of Escherichia coli (Thermo), nutrient agar medium (Merck), water (Brataco), alcohol (Merck), hydrochloric acid (Merck), Chloroform (Merck), acetic acid anhydrous (Merck) and tetracyclines (Merck), and other material with pro analysis grade.

\section{Preparation of Lime Juice Extract}

Lime fruit is squeezed to get lime juice, concentrated with a water bath to form an extract. 


\section{Antibacterial Activity Test}

The method used in this research was modified from Khrisnan et al., 2019. Sterilization is carried out using an autoclave at a temperature $121^{\circ} \mathrm{C}$, pressure 1.5 atm for 15 minutes. The test solution and medium are sterilized by placing them in a test tube or Erlenmeyer, closed, and sterilized by autoclaving. Nutrient agar media is made by weighing 23 grams of nutrient agar powder, dissolved in 1 liter of water, and heated until dissolved, and sterilized in autoclave. The test bacteria are rejuvenated on the medium by scratching the bacteria using a loop needle on the agar surface, then all bacterial cultures are incubated at $37^{\circ} \mathrm{C}$ for 24 hours, taken with loop needle then suspended into $5 \mathrm{~mL}$ of sterile physiological $\mathrm{NaCl}$ solution, and the turbidity is measured using a standard 0.5 Mc Farland. In testing the antibacterial effectiveness using the disc diffusion method.

The test solution is made by dissolving lime juice extract in water to obtain a solution with a concentration of $12.5 \%, 25.0 \%$, $50.0 \%$, and $100.0 \%$. The sterile disc paper is dipped in the test extract solution then left for 30 minutes so that the solvent absorbs into the disc, then placed on the agar surface. For negative control, disc paper was dyed with distilled water and as a positive control using tetracycline $500 \mathrm{mg}$, incubated at $37^{\circ} \mathrm{C}$ for 24 hours.
Antibacterial effectiveness was observed the next day based on the diameter of the inhibition zone or the clear area formed around the disc paper. Measurement of the zone of inhibition using a caliper. The test was repeated 3 times.

\section{RESULTS DISCUSSIONS}

The samples that have been collected are subjected to an extraction process, and testing for antibacterial activity against Escherichia coli.Results of Inhibition Zone Test of Lime Juice Extract against Escherichia coli can be seen in Table 1.

Table 1. Results of Inhibition

Zone Test of Lime Juice Extract against Escherichia coli

\begin{tabular}{ccccc}
\hline \multirow{2}{*}{ Treatment } & \multicolumn{4}{c}{ Inhibition Zone (mm) } \\
\cline { 2 - 5 } & Rep 1 & Rep 2 & Rep 3 & Avrg \\
\hline Water & 0.0 & 0.0 & 0.0 & 0.0 \\
Tetracycline & 20.9 & 20.3 & 19.6 & 20.2 \\
Ex - 12.5\% & 18.4 & 17.8 & 17.6 & 17.9 \\
Ex - 25.0\% & 18.6 & 18.9 & 19.2 & 18.9 \\
Ex - 50.0\% & 19.4 & 19.7 & 19.5 & 19.7 \\
Ex - 100.0\% & 19.8 & 20.1 & 19.9 & 19.9 \\
& & & & \\
\hline Note : "Ex" & & & & \\
means & Replication; "Avrg" & means \\
Average & & & & \\
\end{tabular}

Tetraxycline is an antimicrobial substance obtained by dechlorrination of chlortetracycline, reduction of oxytetracycline, or by fermentation (Borghi and Palma, 
2014). Based on the measurement results of the Escherichia coli antibacterial effectiveness test obtained at a concentration of $100 \%$ had antibacterial activity with an average diameter of the inhibition zone $19.9 \mathrm{~mm}$. The lowest concentration that still provides antibacterial resistance against Escherichia coli is at a concentration of $12.5 \%$ with an average diameter of the inhibition zone of $17.9 \mathrm{~mm}$. This shows that at this concentration there is still antibacterial activity.

The inhibitory activity of plant extracts against tested bacteria can be grouped based on their inhibition zone. The inhibition zone is categorized as strong inhibition if the inhibition zone diameter is more than $20 \mathrm{~mm}$ ( $>20 \mathrm{~mm}$ ), the inhibition zone is categorized as strong inhibition if the inhibition zone diameter is between $10 \mathrm{~mm}$ to $19 \mathrm{~mm}(10 \mathrm{~mm}$ - $19 \mathrm{~mm})$, the inhibition zone is categorized as moderate inhibition if the inhibition zone diameter is between $5 \mathrm{~mm}$ to $10 \mathrm{~mm}$ (5 mm - $11 \mathrm{~mm}$ ). the inhibition zone is categorized as weak inhibition if the inhibition zone diameter is less than $5 \mathrm{~mm}$ ( $<5$ $\mathrm{mm}$ ) (Davis and Stout, 1971 in Elya et al., 2016). From the results obtained, it can be seen that the antibacterial effectiveness test on lime fruit extract is strong.

\section{CONCLUSIONS}

Lime juice extract has antibacterial activity against the Escherichia coli bacteria, the higher concentration, the higher antibacterial activity. At a concentration of $100 \%$ it has the best antibacterial activity with inhibition zone diameter $19.9 \mathrm{~mm}$, there was no significant difference with the inhibition zone of $500 \mathrm{mg}$ tetracycline.

\section{REFERENCES}

Adindaputri, Z., Purwanti, N., dan Wahyudi, I.A. 2013. Pengaruh Ekstrak Kulit Jeruk Nipis (Citrus aurantifolia Swingle) Konsentrasi $10 \%$ Terhadap Aktivitas Enzim

Glukosiltransferase

Streptococcus mutans. Majalah Kedokteran Gigi, 20(2) : 126-131.

Agoes, H.A. 2010. Kimia Farmasi Analisis. Jakarta : Penerbit Salemba Medika. Halaman 3738.

Borghi, A.A., and Palma, M.S.A. 2014. Tetracycline : Production, Waste Treatment and Environmental Impact Assessment. Brazilian Journal of Pharmaceutical Sciences, 50(1) : 25-40.

Davis, W.W., and T.R. Stout. 1971. Disc Plate Method of Microbiological Antibiotic Assay. I. Factors Influencing Variability and Error. Applied Microbiology, 22 : 659-665.

Elya, B., Kusuma, IM., Jufri, M., and Handayani, R. 2016. Antibacterial Tests Against Acne in vitro, the Physical Stability and Patch Test using 
Cream Containing Ethyl pmethoxycinnamate Extracted from Kaempferia galanga L., Rhizoma. Research Journal of Medicinal Plants, 10 (8) : 426434.

Krishnan M., Dey Dk., Sharma, C., and Kang, S.C. 2019. Antibacterial Activity of Weissella confusa by Disc Diffusion Method. Bangladesh Journal of Pharmacology, 14 : 117-122.

Lin, L-Y., Chuang, C-H., Chen, H-S., and Yang, K-M. 2019. Lime (Citrus aurantifolia (Christm.) Swingle) Essential Oils: Volatile Compounds, Antioxidant Capacity, and Hypolipidemic Effect. Foods, 8 : 398. 